Article

\title{
Hydraulic Conductivity and Pore Water Pressures in a Clayey Landslide: Experimental Data
}

\author{
Caterina Di Maio ${ }^{1}$, Jacopo De Rosa ${ }^{1, *}$, Roberto Vassallo ${ }^{1}$, Roberto Coviello ${ }^{2}$ and \\ Giuseppe Macchia ${ }^{2}$ \\ 1 School of Engineering, University of Basilicata. Viale dell'Ateneo Lucano, 10, 85100 Potenza, Italy; \\ caterina.dimaio@unibas.it (C.D.M.); roberto.vassallo@unibas.it (R.V.) \\ 2 Rete Ferroviaria Italiana (Ferrovie dello Stato Italiane Group), Piazza Aldo Moro, 57, 70122 Bari, Italy; \\ r.coviello@rfi.it (R.C.); g.macchia@rfi.it (G.M.) \\ * Correspondence: jacopo.derosa@unibas.it; Tel.: +39-340-5974380
}

Received: 21 February 2020; Accepted: 10 March 2020; Published: 12 March 2020

check for updates

\begin{abstract}
To analyze the response to hydrological conditions of an instable slope in a structurally complex clay formation, the hydraulic conductivity of the subsoil was estimated and pore water pressures were monitored. Two types of field tests were carried out: falling head tests in the Casagrande piezometers and localized seepage measurements in test boreholes. The experimental data show that in a narrow band around the slip surface, the hydraulic conductivity is higher-more than two orders of magnitude- than that of the landslide body and of the stable formation. Furthermore, the data of a long-term monitoring by Casagrande piezometers and vibrating wire cells show that the response of pore water pressures to the site hydrological conditions along the shear band is far faster than in the landslide body and in the stable formation. The slip band seems largely connected to the atmosphere, and the water pressures in the band are correlated with the deep displacement rates of all the inclinometers crossing the active slip surface.
\end{abstract}

Keywords: pore water pressure; hydraulic conductivity; landslide; clay; rain; displacement

\section{Introduction}

Earthflows are widespread in tectonized clayey turbidites of the Italian Apennines; complex and long processes control their evolution. After the first failure, phases of retreat of the alimentation zone, with consequent filling of the landslide channel, are followed by phases of channel emptying with formation and accretion of an accumulation. Typically, rapid movement rates alternate with long dormancy. During the very slow phases, the movements can concentrate on the shear surfaces with a slide character [1,2]. Furthermore, during very slow phases or quiescence, many of the instable areas, in the past, have been urbanized. Year by year, the deformations have accumulated, thus damaging buildings and structures like tunnels and bridges. Since the landslides often extend from the top of the hills or mountains to the river valleys, long linear infrastructures must inevitably cross them. Thus, railways, highways and pipelines need continuous maintenance with high social and economic costs. Public administrations and infrastructure managers often finance surveys and studies aimed at finding stabilization remedies or at least measures of risk reduction. In 2005 and 2010 the Administrative Basilicata Region and in 2011 and 2015 the Italian Ministry of Education, University and Research (MIUR), funded geotechnical studies on the Costa della Gaveta hill, east of Potenza city. Recently, the Italian railway company (Rete Ferroviaria Italiana) funded a further investigation aimed at risk reduction.

The hill slope on the left bank of the Basento river is affected by several types of landslides, among which the Costa della Gaveta landslide in the geological formation of Variegated Clay [3] is one of the 
most important for its extension and for the dense urbanization. The study of its behavior is also important because of the wide diffusion of similar landslides and geological formations in the Italian Apennines. In most cases, such landslides are influenced by the hydrological regime.

Several authors recognized the role of discontinuities as preferential flow paths that facilitate the propagation of pore water pressure associated to rain (among others, [4-8]). The influence of discontinuities on landslide behavior was also discussed by Hencher [9], Sharma \& Nakagawa [10], and Krzerminska et al. [11], for a two-fold mechanism: faster pressure build-up and enhanced drainage. Vitone and Cotecchia [12] and Cotecchia et al. [13] considered fissures as an internal factor predisposing the slope failure from both mechanical and hydraulic points of view. Recently, Tagarelli and Cotecchia [14] carried out a coupled hydro-mechanical numerical analysis on the influence of discontinuities on the behavior of landslides in intensely tectonized clay formations. Ruggeri et al. [15] and Ruggeri et al. [16] also considered the role of discontinuities on the overall behavior of landslides.

The experimental results reported in this paper show that the relatively high values of hydraulic conductivity along the slip band and the connection of this latter to the atmosphere can be responsible for the kinematic response to rain of the Costa della Gaveta landslide. This hypothesis is supported by both the results of a long-term monitoring of pore water pressures in the landslide body, in the stable formation and in the shear band, and the results of permeability tests in the three different zones of the subsoil.

\section{Costa della Gaveta Landslide}

The landslide (Figure 1) develops on the southern slope of a hill, in the Basento river valley, where the Variegated Clay Formation (Upper Cretaceous-Lower Miocene) and the Corleto Perticara Formation (Upper Eocene-Lower Miocene) outcrop [17,18]. The Variegated Clay Formation is constituted by clays, marly shales, cherty marls and marly clays, gray and polychrome, with interbedded layers of calcareous marls, jasper, calcilutites, and turbiditic biocastic calcarenite with fossils and with chert. The Corleto Perticara Formation, first described by Selli [19], consists of alternating layers and benches of marly limestone and massive calcilutites with both plane-parallel and wavy laminations. The sequence of Variegated Clay and Corleto Perticara formations presents a high degree of fractures and joints due to the effects of contractive tectonics. Furthermore, the sequence is cut by a system of faults with orientation NW-SE intersecting a system with NE-SW orientation. The faults have probably influenced the first slope failure and also the subsequent evolution. Currently, the main landslide body develops along the NW-SE fault. In the alimentation zone along the fault NE-SW, localized erosion and rock falls, slides, and earth-debris flows periodically occur and feed the main landslide body [18].
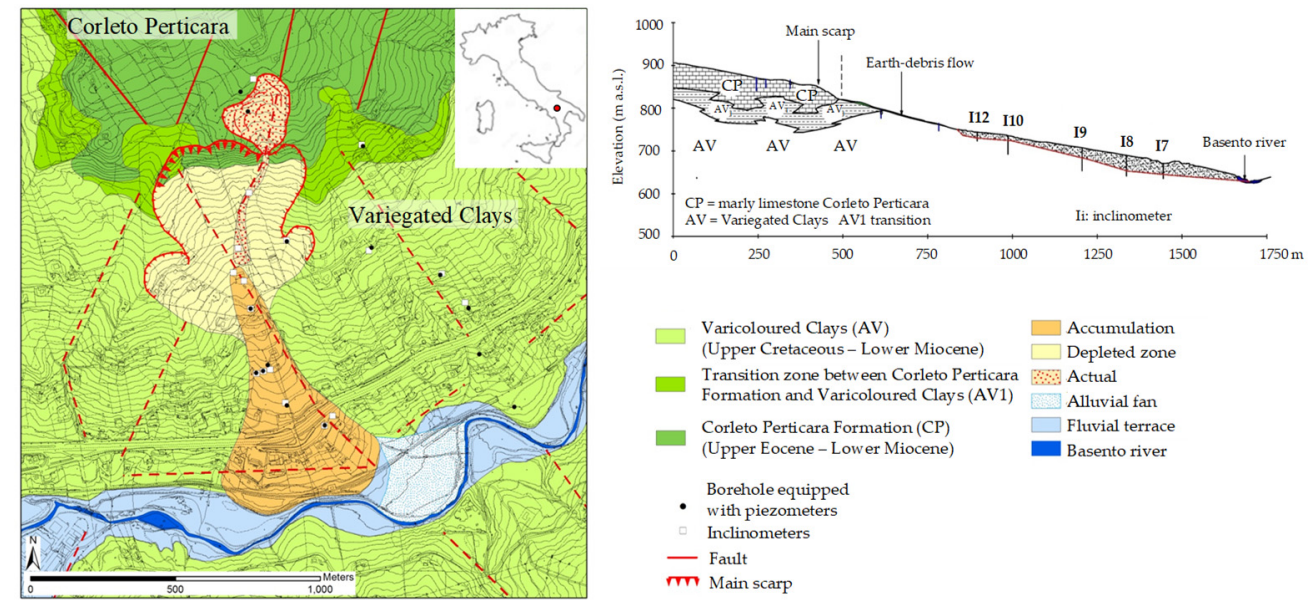

Figure 1. Geological map and axial section of the Costa della Gaveta landslide (redrawn from Vassallo et al. [18]). 
The landslide presents a chaotic fabric with a clayey matrix incorporating rock fragments, blocks, and disarranged strata of marly limestone and calcarenite; the clayey matrix controls its behavior.

The clay fraction c.f. of the matrix ranges between $25 \%$ and $50 \%$ (Figure 2). Illite-muscovite and kaolinite are the main clay mineral components; locally, chlorite and smectite reach percentages of about $20 \%$ [20]. The liquid limit generally ranges between $50 \%$ and $80 \%$ but can reach values higher than $100 \%$. The degree of saturation of the shallow soil cover (about $2 \mathrm{~m}$ thick) undergoes seasonal variations different from place to place in the slope. The average water content of the saturated zone decreases from about $25 \%$ in the landslide body to about $15 \%$ in the stable formation beneath (Figure 2). Di Maio et al. [17] argued that the shear strengths available on the slip surface are close to the residual values. The residual friction angle $\varphi^{\prime}{ }_{\mathrm{r}}$ was evaluated by means of the Casagrande direct shear and the Bishop ring shear devices, obtaining a very similar result. Values in the range $6^{\circ}-10^{\circ}$ were obtained, depending on the clay fraction, clay mineral composition, and pore fluid composition [21,22].
c.f. (\%)
w (\%)
w (\%)
$\mathrm{w}_{\mathrm{L}}(\%)$
$\begin{array}{llllll}0 & 10 & 20 & 30 & 40 & 50\end{array}$
$\begin{array}{llllll}0 & 10 & 20 & 30 & 40 & 50\end{array}$
$\begin{array}{lllll}0 & 25 & 50 & 75 & 100\end{array}$




Figure 2. Clay fraction c.f., water content $\mathrm{w}$ and liquid limit $\mathrm{w}_{\mathrm{L}}$ against depth from the ground surface.

The landslide body, with an average inclination of about $10^{\circ}$, is approximately $1250 \mathrm{~m}$ long, from 100 to $600 \mathrm{~m}$ wide; the maximum slip surface depth provided by the inclinometers is about $40 \mathrm{~m}$ (Figure 3) and the soil volume is about $3 \times 10^{6} \mathrm{~m}^{3}$. The landslide movements have been monitored by inclinometers since 2004, by GPS since 2006 [23], and recently by Cosmo SkyMed [24]. The interpretation of the experimental data (Figures 3 and 4) suggests that: 1) sliding localized along a thin slip zone is the current prevailing type of movement, while internal shear strains are important in the shallow soil cover; 2) the displacement rate can be considered uniform in the cross sections of the landslide body; 3 ) the average yearly rates of deep displacements AB (Figure 3) can be considered constant over the monitoring time; 4) such average yearly rates decrease in the downslope direction. On the basis of inclinometer profiles and geomorphologic elaborations, Di Maio et al. [17] hypothesized that the soil volumes crossing in the unit time the transversal sections of the main track are very close to each other: i.e., the landslide moves in the main track with constant soil discharge. 

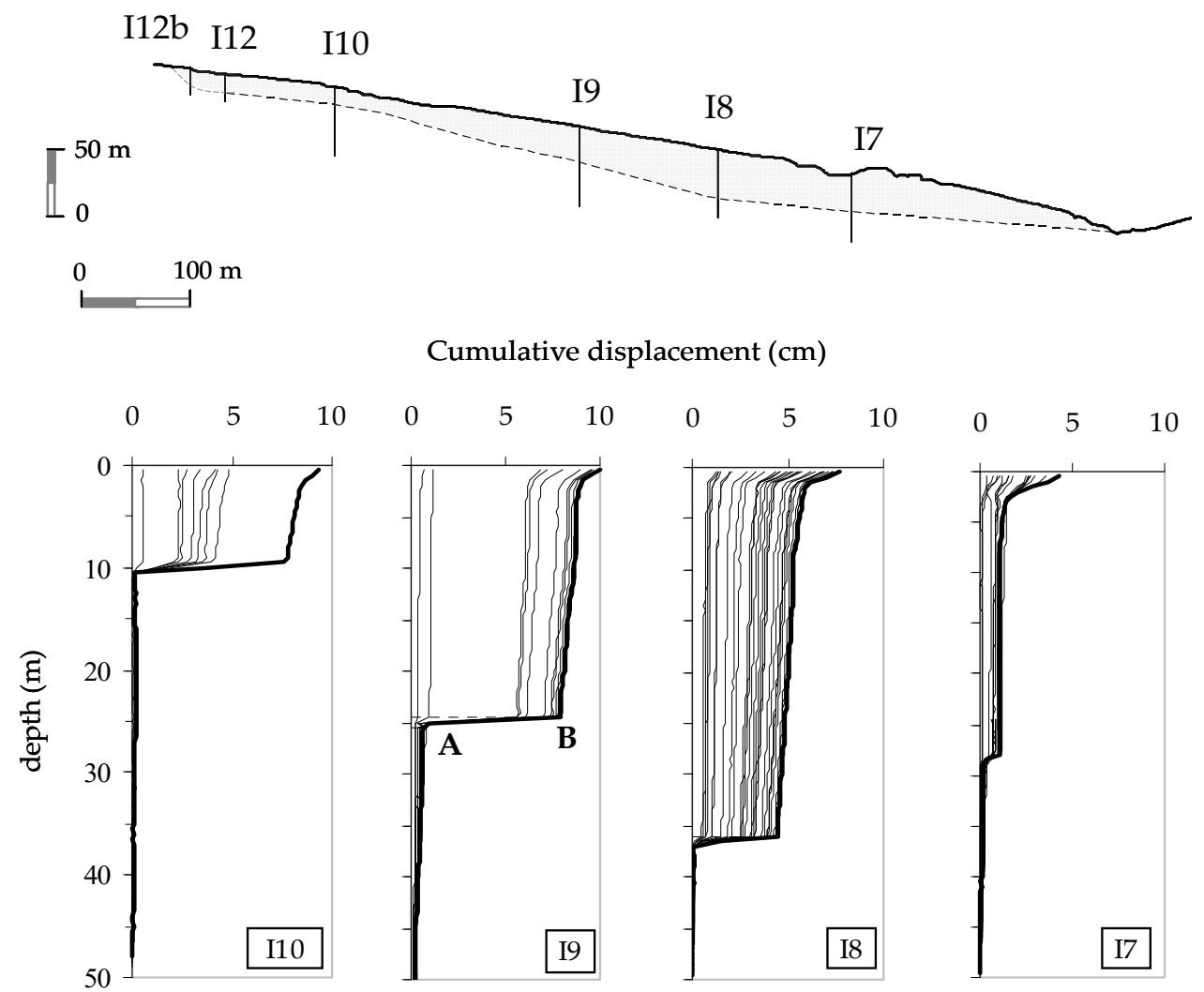

Figure 3. Location of inclinometer verticals in the axial section and displacement profiles in some verticals.



Figure 4. Deep displacements AB against time.

According to Guida e Iaccarino [1], who analyzed a large number of landslides in the Basento valley, and to Urciuoli et al. [2], the Costa della Gaveta landslide is an earthflow that underwent a first stage of mobilization and flow (stage A), a second stage of flow within well defined lateral shear surface (stage $B$ ), and is nowadays in a phase (stage $\mathrm{C}$ ) characterized by defined morphological features and movements, from slow to extremely slow, of slide type. A return to flow stages A and/or B is possible. According to the classification by Hungr et al. [25], the landslide can be defined as an earthflow which, at present, is in a slow, almost steady-state phase, with deformations concentrated on shear surface.

Within the linear time trend of yearly displacement rate, seasonal variations can be distinguished. Actually, the curves of cumulated displacements and cumulated rain exhibit very similar time trends 
(Figure 5). The existence of a correlation between rain and displacement rate has been shown by Vassallo et al. [26]. In the case under study, in which total stresses are practically constant, rain can affect the displacement rate through an influence on pore water pressures and thus on effective stresses [27]. This is not obvious because the slip surface is deep (up to $40 \mathrm{~m}$ ) and the high clay fraction contributes to lowering the hydraulic conductivity. So, to have a deeper insight into the response of the landslide to hydrological processes, pore water pressures were monitored and the hydraulic conductivity was evaluated in several different locations of the landslide and at different depths from the ground surface.

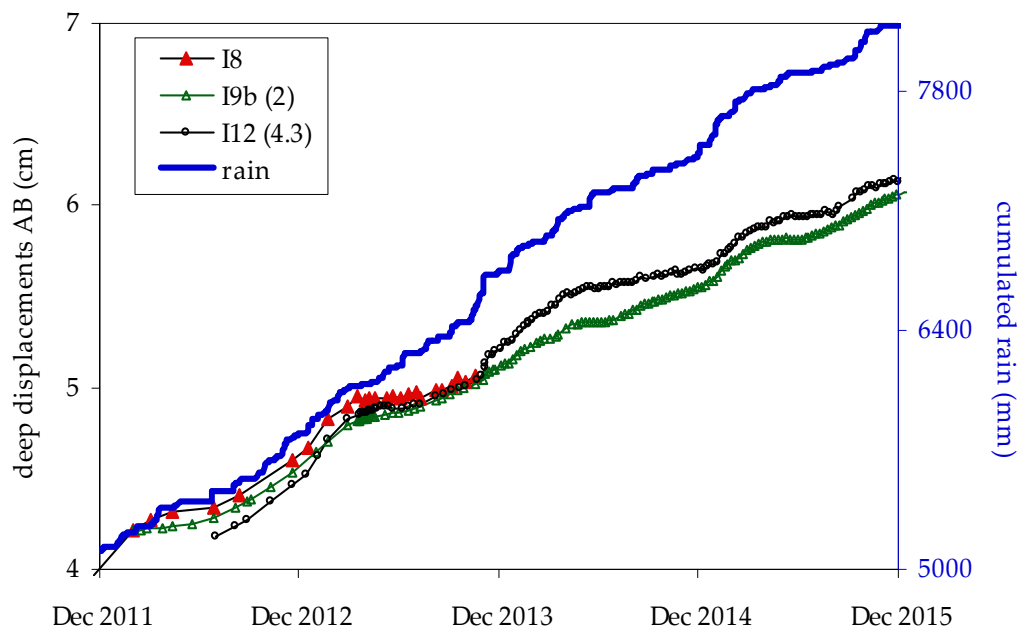

Figure 5. Deep displacements $A B$ and cumulated rain against time. The displacement series are divided by the constants indicated between brackets in the legend.

\section{Field Tests to Evaluate Hydraulic Conductivity}

The hydraulic conductivity was evaluated by interpreting and modeling the seepage occurring in test boreholes used as pumping wells; localized measures of water flow were carried out all along the hole walls by means of a device constructed ad hoc. Furthermore, falling head tests were carried out by standard procedures (ASTM D5084) in all the Casagrande piezometers installed in the slope.

\subsection{Localized Seepage Measurements in Pumping Wells}

For localized water flow evaluation, 11 test boreholes Ki were drilled, in the landslide head in October 2015, crossing the slip zone (Figures 6 and 7). The localized seepage measurements were performed in these boreholes by a permeameter constituted of a cylindrical cell of $7 \mathrm{~cm}$ diameter and $15 \mathrm{~cm}$ height, equipped with two sealing rubbers. The cell is mounted at the end of a series of hollow rods in which the galvanometric probe can be inserted (Figure 8a). During the test, the free water surface in the borehole is kept at a given depth, below the slip surface, until steady-state seepage conditions are reached in the borehole itself and constant hydraulic head is observed in the boreholes around it (up to about 10 days required). Once the steady-state conditions are achieved, the cell is installed at the desired depth and the elevation of the free surface of the inflowing water is monitored. The specific discharge draining from the well wall is thus evaluated.

Figure 7 shows the time trend of the specific discharge flowing in the cell installed at a depth of $8.8 \mathrm{~m}$ in the borehole $\mathrm{K} 3$. In this case, the test was repeated three times. It can be observed that: a) the test is highly repeatable, b) the specific discharge $q$, initially in the order of a few $\mathrm{cm} / \mathrm{h}$, decreases with considerable gradients for about 5 days and, after about 10 days, reaches a constant value. The tests were carried out with continuity along the height of the same borehole, and of other boreholes, thus obtaining the profiles of specific discharge in steady-state conditions shown by Figure $8 \mathrm{~b}$. Figure $8 \mathrm{c}$ shows also further experimental data relative to nonstationary conditions (about 10 hours from the beginning of the test), recorded in different seasons, consistent with the previous ones. All the data reveal that the greatest inflows occur in narrow bands about $0.2 \mathrm{~m}-0.5 \mathrm{~m}$ thick at depths varying with 
the boreholes between $7.5 \mathrm{~m}$ and $9 \mathrm{~m}$. In this range of depths, the nearby inclinometer tubes undergo concentrated deformations (Figure 8d) which can be interpreted as due to the landslide displacements along the slip band.

The test processes were simulated by 2D, 3D, and axisymmetric models based on finite element and finite differences methods [28,29]. Values of thickness of the more permeable band between 20 and $50 \mathrm{~cm}$ were considered, hydraulic conductivities $\mathrm{k}_{\mathrm{f}}=10^{-10} \mathrm{~m} / \mathrm{s}$ for the stable formation, and value $\mathrm{k}_{\mathrm{lb}}=10^{-9} \mathrm{~m} / \mathrm{s}$ for the landslide body were assumed (both values obtained by falling head test in the piezometers). The values of the band hydraulic conductivity $\mathrm{k}_{\mathrm{sb}}$ which allow the best modelization are in the range $10^{-7} \mathrm{~m} / \mathrm{s}<\mathrm{k}_{\mathrm{sb}}<10^{-5} \mathrm{~m} / \mathrm{s}$. Thus, on the basis of this analysis, the slip band is much more permeable than the other zones of the subsoil, by some orders of magnitude.

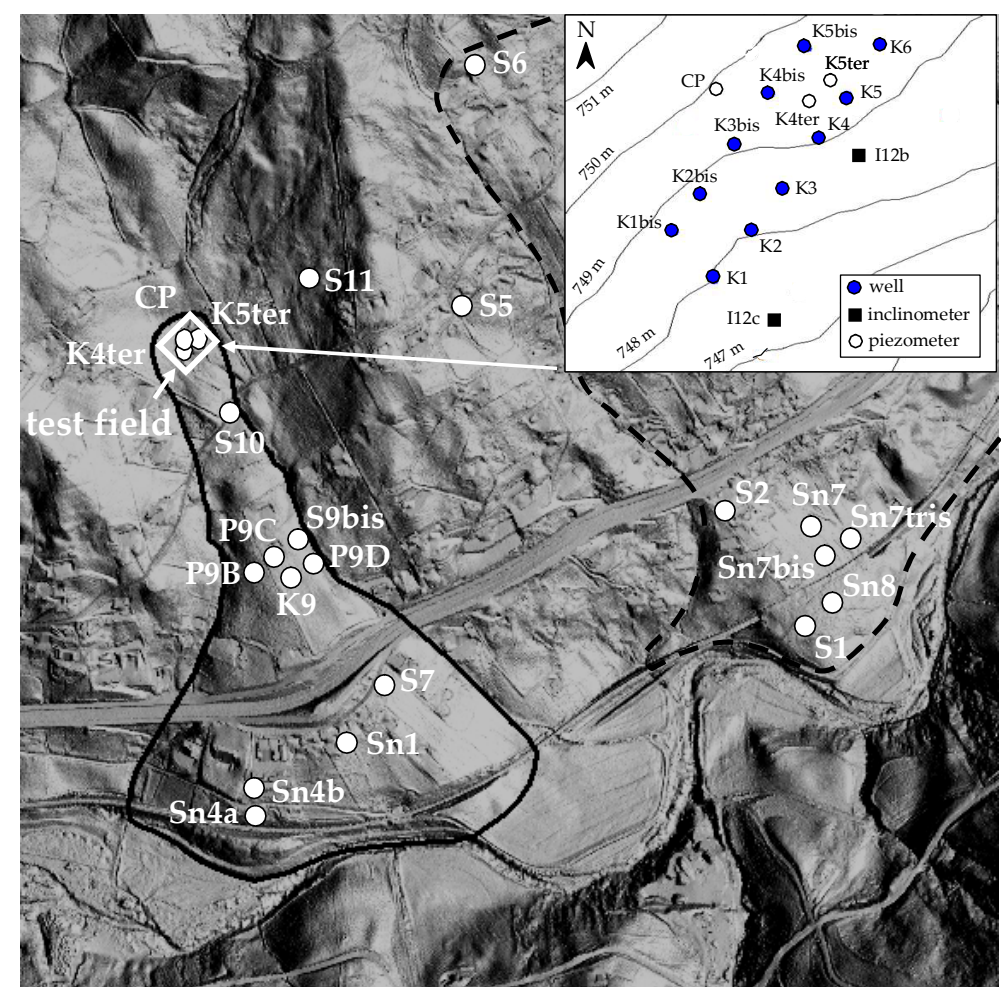

Figure 6. Map of the Costa della Gaveta slope with location of a test field, piezometers, open tubes, and boundaries of Costa della Gaveta landslide and east of it, the Varco d'Izzo landslide system.



Figure 7. Specific discharge flowing in the permeameter against time in the transient induced by water level drawdown in the borehole $\mathrm{K} 3$ at a depth of $8.8 \mathrm{~m}$. 
a)



c) specific discharge
$\mathrm{q}(\mathrm{cm} / \mathrm{h})$

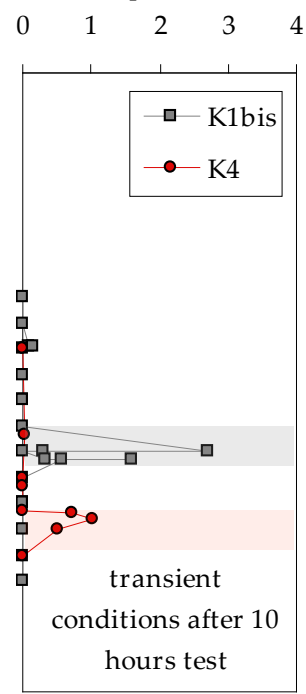

d) displacement profile (cm)



Figure 8. Scheme of the permeameter (a), profiles of specific discharge in: steady-state conditions (b), and after about 10 hours from the beginning of the test (c); displacement profiles of the nearby inclinometers (d). Figure $8 \mathrm{~b}$ also shows the results of an axysimmetric FEM model (GEO-SLOPE).

\subsection{Falling Head Tests in Casagrande Piezometers}

Falling head tests were carried out in all the Casagrande piezometers installed in the slope, including the nearby Varco d'Izzo landslide system (Figure 6), in the same geological formation. After the results of the localized seepage measurements, some piezometers were also installed in the slip band. In each piezometer, the test was repeated several times in different seasons.

The results show that the equalization rate for the piezometers installed in the slip band is very high, both in the landslide head and in the channel, and it is higher than elsewhere (Figure 9). The interpretation of the tests was carried out by using the Hvorslev model based on the assumption of Darcy's law validity and on the incompressibility of soil and water [30]. In the case of the slip band, the shape factor F relative to permeable layer between impervious strata (case 9 according to Hvorslev scheme) was considered.

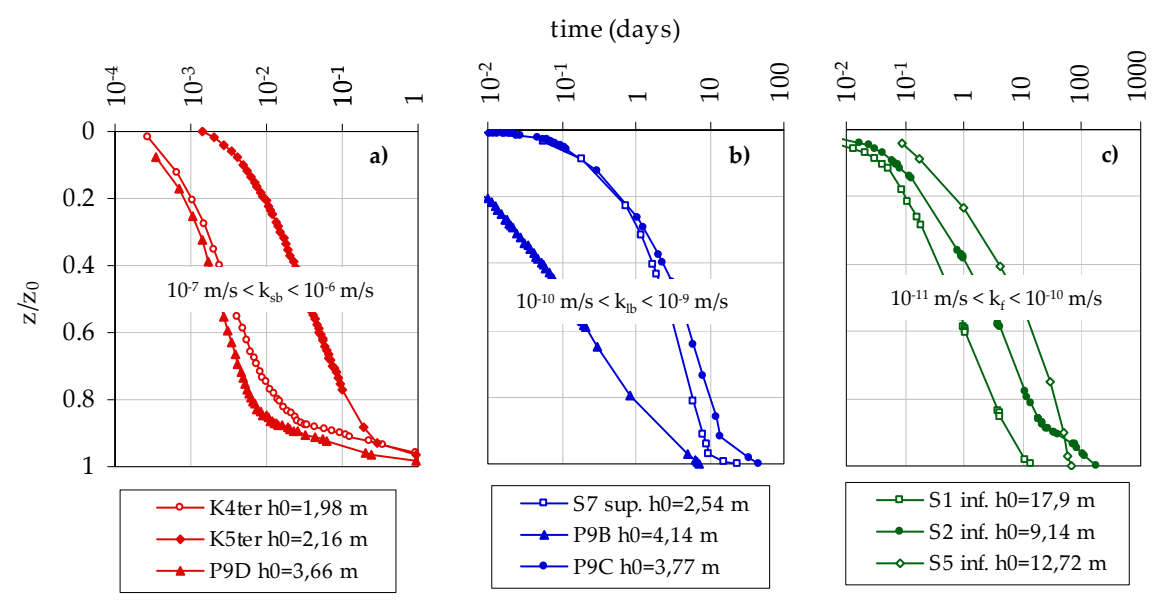

Figure 9. Falling head tests by Casagrande piezometers: ratio between the depth of the current water surface, $z$, and of the equilibrium depth, $z_{0}$, in: (a) the slip band; (b) the landslide body; (c) the stable formation. 
Assuming the thickness of the slip band between $0.2 \mathrm{~m}$ and $0.5 \mathrm{~m}$, the model provides values of hydraulic conductivity $\mathrm{k}_{\mathrm{sb}}$ in the range $10^{-7} \mathrm{~m} / \mathrm{s}-10^{-6} \mathrm{~m} / \mathrm{s}$. Variations lower than an order of magnitude are obtained by using different reasonable $\mathrm{F}$ values. For the piezometers in the landslide body and in the stable formation, if $\mathrm{F}$ is considered relative to case 8 (uniform soil), the values of the hydraulic conductivity are about $10^{-9} \mathrm{~m} / \mathrm{s}$ and $10^{-10} \mathrm{~m} / \mathrm{s}$ respectively. Values of hydraulic conductivity in the slip band similar to those obtained by the Hvorslev model were obtained by using an axysimmetric FEM model (code GEO-SLOPE Ltd.). Figure 10 compares the values of hydraulic conductivity estimated by the two different types of field tests and also by laboratory test results. The latter were obtained by interpreting the oedometric consolidation curves with the Terzaghi one-dimensional model. As expected, the values relative to the small elements of soil are much lower than the field values, due to the great influence of fabric, inhomogeneity, and discontinuities that characterize the formation and, even more, the landslide. The figure shows that the results of the falling head tests are very similar to those obtained by seepage-pumping tests, and both types of data emphasize that the slip band is much more permeable, by some orders of magnitude, than the other zones of the subsoil.

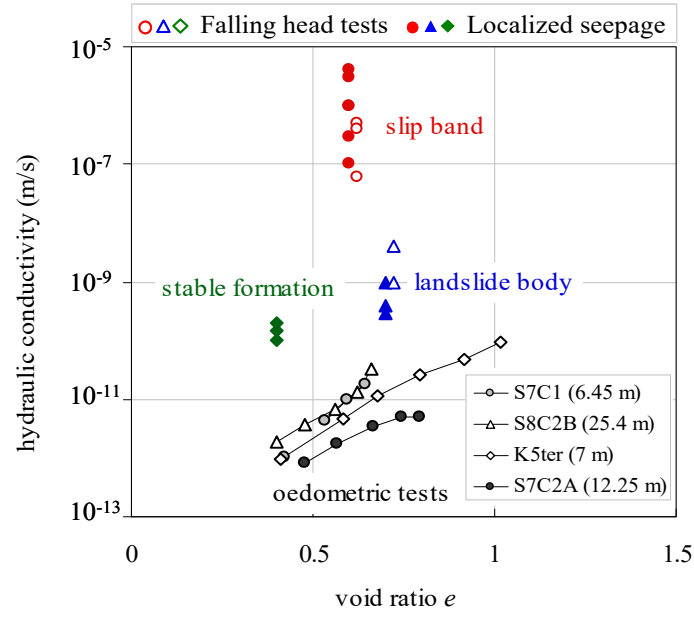

Figure 10. Hydraulic conductivity in the different zones of the subsoil determined by different types of field test and by oedometer tests on undisturbed samples.

\section{Pore Water Pressures and Displacement Rate}

Pore water pressures have been monitored since 2005 by the Casagrande piezometers and by some vibrating wire cells (Figure 11a). Recently, in 2018, new instruments have been installed (Figure 11b). The data can be represented all together, in the same figure, in terms of depth of water surface from the ground, as in Figure 11. The figure indicates small seasonal variations in water depth in the stable formation and in the landslide body. Even the electric cells installed at about $8 \mathrm{~m}$ and $4 \mathrm{~m}$ depth in the accumulation and in the head zone respectively of Costa delle Gaveta landslide do not show a seasonal response to rain. On the contrary, the piezometers installed in its slip zone (K4ter, K5ter, and P9D) indicate noticeable seasonal variations. Figure 12a reports the water surface depth in the Casagrande piezometers K4ter (8 $\mathrm{m}$ depth), K5ter $(8 \mathrm{~m})$, and P9D $(25 \mathrm{~m})$. The figure also reports the water surface depth in the open tubes $\mathrm{K} 9(30 \mathrm{~m})$ and $\mathrm{Ki}(11-15 \mathrm{~m})$ in the tests field. Although these latter values do not refer to localized measures, they can reasonably be considered representative of pore water pressure on the slip band because of the high band values of hydraulic conductivity, which are much higher than in the surrounding soil. As a matter of fact, the figure shows the good agreement of the time trend of all the data and gives an idea of the reduction with depth of rain effects. In fact, K4ter, $\mathrm{K} 5$ ter, and $\mathrm{Ki}$ are located in the head of the landslide, where the depth of the sliding surface is about 8 $\mathrm{m}$, whereas P9D and K9 are located in the middle of the landslide body, where the slip surface depth is about $25 \mathrm{~m}$. Accordingly, pore pressures in Ki, K4ter, and K5ter oscillate more than in K9 and P9D. The modeling of the observed behavior is under examination. 

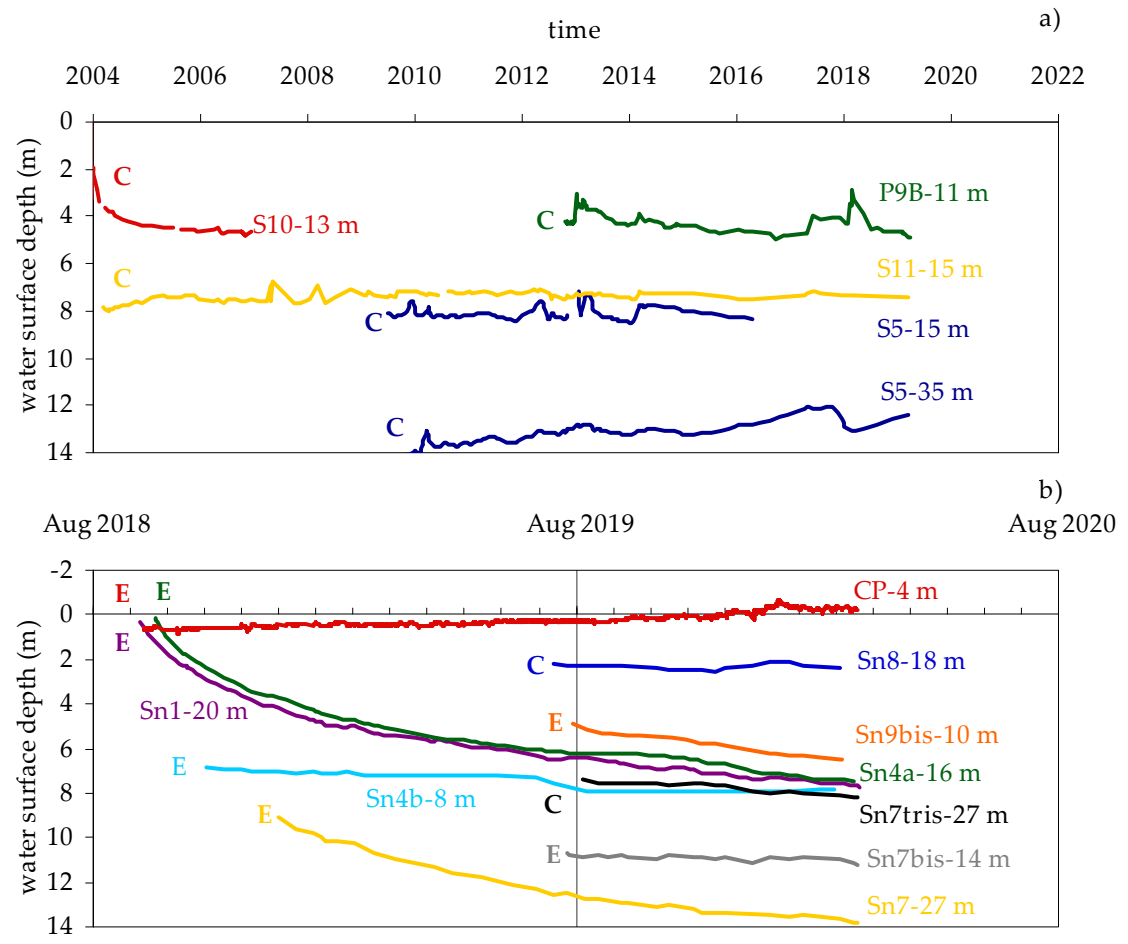

Figure 11. Water surface depth from the ground evaluated by different types of piezometers at different depths: (a) since 2004; and (b) since 2018. The letters C and E indicate the Casagrande piezometers and the electric vibrating wire cells respectively. For the latter instruments, an equivalent water surface depth was evaluated from water pressure data.

a)

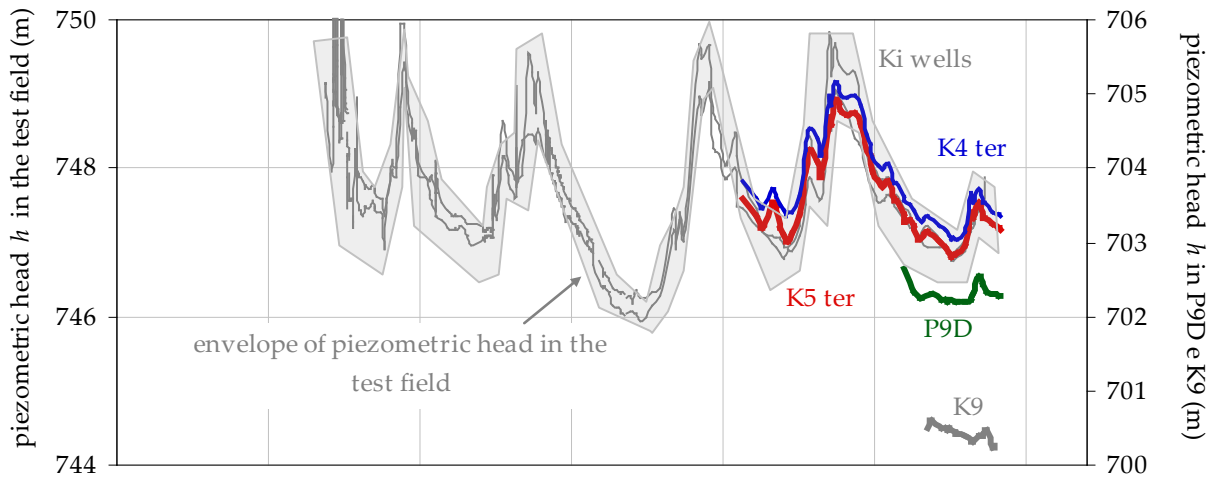

b)

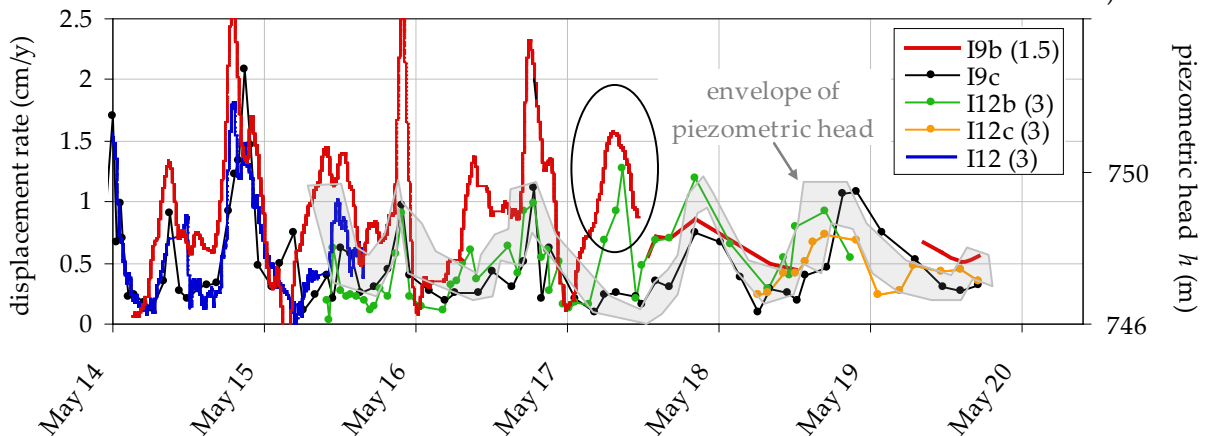

Figure 12. Piezometric head $h$ evaluated in piezometers installed in the slip band and in wells crossing it (a), and time trend of deep displacement rates divided by the constant indicated between brackets in the legend (b). 
The rates of deep displacements evaluated by fixed in place and mobile inclinometers are very low. Scaringi and Di Maio [21,22] showed that they vary in a range for which the laboratory test results show no influence on the soil residual friction angle. These low rates vary from a few $\mathrm{cm} / \mathrm{year}$ in the head of the landslide to a few $\mathrm{mm} /$ year in the accumulation, responding to the hypothesized mechanism of constant soil discharge. The ratio between the rates in the different transversal sections is therefore roughly equal to the inverse ratio of the areas of the sections [17,31]. Figure 12b reports deep displacement rate against time in some different verticals. Each curve is represented by dividing the displacement rate by a constant which makes comparable the average yearly rates. It can be observed that, with the exception of the circled peaks, the rates' variations are very similar to pore water pressure variations (represented by the grey envelope of piezometric head), thus showing the existence of a strong correlation between pore water pressures and deep displacement rates.

\section{Discussion and Conclusions}

Summing up, the long-term monitoring shows that the average yearly rates of deep displacements in the main channel of the landslide have been almost constant over the 15 years of monitoring. Over the linear average yearly trend, the weekly displacement rates have exhibited seasonal variations almost synchronic with those of cumulated rain. The permeability tests show that the slip band is rather permeable and it is the most permeable zone of the considered slope. Pore water pressures along the slip band respond to rain, suggesting that this permeable zone is connected to the atmosphere. The rate of deep displacements varies in phase with water pressure on the slip surface in all the inclinometers.

The correlation between displacement rates and rainfall was quantitatively confirmed by Vassallo et al. [26] by using a data-driven evolutionary modeling technique. The model links the series of data with polynomial relationships, the coefficients of which are optimized by a minimum square method. A rather strong correlation was found with contemporary rainfall, whereas the influence of past rainfall decreases exponentially with time. In the considered case, total stresses can be considered constant over the year, thus rain can influence the displacement rates through an influence on pore water pressures, i.e., on effective stresses on the slip surface. However, this latter is deep (up to $40 \mathrm{~m}$ ) and the soil permeability is generally low.

In the literature, several attempts have been made to evaluate the depth effect for homogeneous slopes (e.g., [32-34]). In low permeability soils it seems reasonable to hypothesize a strong reduction of pore water pressure fluctuations. As a matter of fact, the piezometric data relative to the landslide body show that rain does not influence pore water pressures in the soil at even $4 \mathrm{~m}$ depth. However, the data show that pore water pressures vary quickly with rain on the slip band at $8 \mathrm{~m}$ depth in the landslide head (K4ter, K5ter) and even at $25 \mathrm{~m}$ in the channel (P9D). Thus, the slip band, which is shown to be the zone with the highest permeability, is physically connected to the atmosphere. Besides its intersection with the ground surface, the connection can occur by several types of discontinuities which make the response to rain faster.

The results of permeability and seepage tests show that preferential water flow occurs in the narrow band where the inclinometers undergo concentrated deformations. The modeling of the different types of permeability tests provides permeability values in the range $10^{-7} \mathrm{~m} / \mathrm{s}<\mathrm{k}_{\mathrm{sb}}<10^{-5}$ $\mathrm{m} / \mathrm{s} 10^{-10} \mathrm{~m} / \mathrm{s}<\mathrm{k}_{\mathrm{lb}}<10^{-9} \mathrm{~m} / \mathrm{s}, 10^{-11} \mathrm{~m} / \mathrm{s}<\mathrm{k}_{\mathrm{f}}<10^{-10} \mathrm{~m} / \mathrm{s}$, respectively in the slip band, in the landslide body, and in the stable formation. The continuous displacements along the slip band are probably responsible for an open fabric that facilitates water flow; however, the cause of a so large increase in the band permeability is currently under examination.

The time trends of the displacement rate and pore water pressures on the slip band are similar. This suggests that the experimental results obtained in two limited zones of the landslide are likely to occur in a large portion of the slip surface, sufficient to influence the landslide kinematics.

The consequences on landslides' behavior of hydraulic conductivity inhomogeneties can be important. Urciuoli et al. [2,35] hypothesized that, due to the presence of discontinuities, the response of pore water pressures to rain in some parts of the landslides can occur faster and more intensely 
than in others, thus influencing the complex landslide kinematics. Vitone and Cotecchia [12] and Cotecchia et al. [13], while analyzing the instability processes in intensely fissured clays of the Southern Apennines, observed that fissuring can be considered an internal factor predisposing the slope to failure both for its effects on strength parameters and on the clay permeability. In fact, fissuring makes an increase of the pore water pressures down to large depths possible.

The existence of a more permeable slip zone must be kept in due consideration in the design of drain systems. For instance, in the case under examination, first calculations show that an effective drain system must intersect the slip band, otherwise rain can act faster than drainage [36].

Moreover, the first experimental results seem to show that the water flow along the slip band can also produce a reduction in the ion concentration of the pore solution, with possible negative consequences on the soil shear strength [37-40]. On the other side, recent results of field and laboratory experimentation show that an increase of given cations in the pore fluid can increase greatly and permanently the strength parameters on the slip band and can reduce creep movements [41,42]. The current and future research is directed to designing systems of drains reaching the slip surfaces integrated with systems of salt solutions' wells.

Author Contributions: Conceptualization, methodology, software, validation, formal analysis, investigation, resources, data curation, writing—original draft preparation, writing—review and editing, visualization, C.D.M., J.D.R., R.V.; supervision, project administration, funding acquisition, R.C., G.M. All authors have read and agreed to the published version of the manuscript.

Funding: The geotechnical investigation was funded by the Administrative Basilicata Region, by the Italian Ministry of Education, University and Research (PRIN 2015: Innovative Monitoring and design strategies for sustainable landslide risk mitigation) and by Ferrovie dello Stato Italiane Group (RFI).

Acknowledgments: The authors wish to thank Eng. A. Marotta and M. Belvedere who carried out in situ measurements.

Conflicts of Interest: The authors declare no conflict of interest.

\section{References}

1. Guida, G.; Iaccarino, G. Fasi evolutive delle frane tipo colata nell'alta valle del F.Basento (Potenza). Proc. Studi Trentini di Scienze Naturali, Acta Geol. 1991, LCVIII, 127-152.

2. Urciuoli, G.; Comegna, L.; Di Maio, C.; Picarelli, L. The Basento Valley: A natural laboratory to understand the mechanics of earthflows. Riv. Ital. Di Geotec. 2016, 50, 71-90.

3. Pescatore, T.; Renda, P.; Tramutoli, M. Rapporti tra le unità lagonegresi e le unità sicilidi nella media valle del Basento, Lucania (Appennino Meridionale). Mem. Soc. Geol. IT. 1988, 41, 353-361.

4. Brunsden, D. Some geomorphological considerations for the future development of landslide models. Geomorphology 1999, 30, 13-24. [CrossRef]

5. Shao, W.; Bogaard, T.; Bakker, M.; Berti, M. The influence of preferential flow on pressure propagation and landslide triggering of the Rocca Pitigliana landslide. J. Hydrol. 2015, 543, 360-372. [CrossRef]

6. Bogaard, T.A.; Greco, R. Landslide hydrology: From hydrology to pore pressure. Wires Water 2016, 3, 439-459. [CrossRef]

7. Belle, P.; Aunay, B.; Lachassagne, P.; Ladouche, B.; Join, J.-L. Control of tropical landcover and soil properties on landslides' aquifer recharge, piezometry and dynamics. Water 2018, 10, 1491. [CrossRef]

8. Sidle, R.C.; Greco, R.; Bogaard, T.A. Overview of Landslide Hydrology. Water 2019, 11, 148. [CrossRef]

9. Hencher, S.R. Preferential flow paths through soil and rock and their association with landslides. Hydrol. Process. 2010, 24, 1610-1630. [CrossRef]

10. Sharma, R.; Nakagawa, H. Numerical model and flume experiments of single and two-layered hillslope flow related to slope failure. Landslides 2010, 7, 425-432. [CrossRef]

11. Krzeminska, D.M.; Bogaard, T.A.; Malet, J.P.; van Beek, L.P.H. A model of hydrological and mechanical feedbacks of preferential fissure flow in a slowmoving landslide. Hydrol. Earth Syst. Sci. 2013, 17, 947-959. [CrossRef]

12. Vitone, C.; Cotecchia, F. The influence of intense fissuring on the mechanical behaviour of clays. Géotechnique 2011, 61, 1003-1018. [CrossRef] 
13. Cotecchia, C.; Vitone, C.; Santaloia, F.; Pedone, G.; Bottiglieri, O. Slope instability processes in intensely fissured clays: Case histories in the Southern Apennines. Landslides 2015, 12, 877-893. [CrossRef]

14. Tagarelli, V.; Cotecchia, F. The Effects of Slope Initialization on the Numerical Model Predictions of the Slope-Vegetation-Atmosphere Interaction. Geosciences 2020, 10, 85. [CrossRef]

15. Ruggeri, P.; Fruzzetti, V.M.E.; Scarpelli, G. Design Strategies to Mitigate Slope Instabilities in Structurally Complex Formations. Geosciences 2020, 10, 82. [CrossRef]

16. Ruggeri, P.; Fruzzetti, V.M.E.; Ferretti, A.; Scarpelli, G. Seismic and Rainfall Induced Displacements of an Existing Landslide: Findings from the Continuous Monitoring. Geosciences 2020, 10, 90. [CrossRef]

17. Di Maio, C.; Vassallo, R.; Vallario, M.; Pascale, S.; Sdao, F. Structure and kinematics of a landslide in a complex clayey formation of the Italian Southern Apennines. Eng. Geol. 2010, 116, 311-322. [CrossRef]

18. Vassallo, R.; Grimaldi, G.M.; Di Maio, C.; Di Nocera, S. An earthflow in structurally complex formations of the Italian Southern Apennines: Geological structure and kinematics. In Proceedings of the 12th International Symposium on Landslides, Naples, Italy, 12-19 June 2016; Aversa, S., Cascini, L., Picarelli, L., Scavia, C., Eds.; CRC Press: Boca Raton, FL, USA, 2016; Volume 2, pp. 813-820.

19. Selli, R. II Paleogene nel quadro della geologia dell'Italia centro meridionale. Mem. Soc. Geol. IT. 1962, 3, 737-789.

20. Summa, V. Final Report of the Project "Monitoring of Costa DELLA GAVETA Landslide in Potenza", in Italian; CNR-IMAA: Tito, Italy, 2006.

21. Scaringi, G.; Di Maio, C. Residual shear strength of clayey soils: The influence of displacement rate. In Proceedings of the 2nd Conference for PhD students in Civil Engineering, Cluj-Napoca, Romania, 10-13 December 2014; UT Press: Cluj-Napoca, Romania, 2014; Volume 1, pp. 325-332.

22. Scaringi, G.; Di Maio, C. Influence of displacement rate on residual shear strength of clays. Procedia Earth Planet. Sci. 2016, 16, 137-145. [CrossRef]

23. Calcaterra, S.; Di Maio, C.; Gambino, P.; Vallario, M.; Vassallo, R. Surface displacements of two landslides evaluated by GPS and inclinometer systems: A case study in Southern Apennines, Italy. Nat. Hazards 2012, 61, 257-266. [CrossRef]

24. Vassallo, R.; Calcaterra, S.; De Rosa, J.; Di Maio, C.; Gambino, P. Long-term displacement monitoring of two very slow earthflows by inclinometers, GPS and Cosmo-SkyMed data. Submitted Geosci. 2020. Under Review.

25. Hungr, O.; Leroueil, S.; Picarelli, L. The Varnes classification of landslide types, an update. Landslides 2014, 11, 167-194. [CrossRef]

26. Vassallo, R.; Doglioni, A.; Grimaldi, G.M.; Di Maio, C.; Simeoni, V. Relationships between rain and displacements of an active earth flow: A data driven approach by EPRMOGA. Nat. Hazards. 2016, 81, 1467-1482. [CrossRef]

27. Vassallo, R.; Grimaldi, G.M.; Di Maio, C. Pore water pressures induced by historical rain series in a clayey landslide: 3D modeling. Landslides 2015, 12, 731-744. [CrossRef]

28. De Rosa, J.; Pontolillo, D.M.; Caputo, V.; Di Maio, C.; Scaringi, G. Evaluation of hydraulic conductivity in the slip zone of an earthflow in clay shales. In Proceedings of the XVII European Conference on Soil Mechanics and Geotechnical Engineering ECSMGE, Reykjavik, Iceland, 1-6 of September 2019; Sigursteinsson, H., Erlingsson, S., Bessason, B., Eds.; ISSMGE Online Library, 2019; pp. 546-552.

29. Grimaldi, G.M.; Pontolillo, D.M.; De Rosa, J.; Rizzo, E.; Di Maio, C. Modelling water flow and ion transport in clay soils: The case of $\mathrm{KCl}$ wells in the head of an earthflow. In Micro to MACRO Mathematical Modelling in Soil Mechanics, Trends in Mathematics; Giovine, P., Mariano, P.M., Mortara, G., Eds.; Birkhauser: Basel, Switzerland, 2018; pp. 159-167.

30. Hvorslev, M.J. Time lag and soil permeability in ground-water observations.Waterways experimentary station. Corps of Engineers, US Army. Vicksburg, Mississipi. Bulletin 1951, 36, 50.

31. Di Maio, C.; Vassallo, R.; Vallario, M. Plastic and viscous shear displacements of a deep and very slow landslide in stiff clay formation Eng. Geol. 2013, 162, 53-66.

32. Kenney, T.C.; Lau, K.C. Temporal changes of groundwater pressure in a natural slope of nonfissured clay. Can. Geotech. J. 1984, 21, 138-146. [CrossRef]

33. Conte, E.; Troncone, A. Soil layer response to pore pressure variations at the boundary. Géotechnique 2008, 58, 37-44. [CrossRef] 
34. Conte, E.; Troncone, A. Stability analysis of infinite clayey slopes subjected to pore pressure changes. Géotechnique 2012, 62, 87-91. [CrossRef]

35. Urciuoli, G.; Pirone, M.; Comegna, L.; Picarelli, L. Long-term investigations on the pore pressure regime in saturated and unsaturated sloping soils. Eng. Geol. 2016, 212, 98-119. [CrossRef]

36. Di Maio, C.; Vassallo, R. Geotechnical characterization of a landslide in a Blue Clay slope. Landslides 2011, 8, 17-32. [CrossRef]

37. Di Maio, C.; Scaringi, G.; Vassallo, R. Residual strength and creep behaviour on the slip surface of specimens of a landslide in marine origin clay shales: Influence of pore fluid composition. Landslides 2015, 12, 657-667.

38. Di Maio, C.; Scaringi, G. Shear displacements induced by decrease in pore solution concentration on a pre-existing slip surface. Eng. Geol. 2016, 200, 1-9. [CrossRef]

39. Di Maio, C.; Vassallo, R.; Scaringi, G.; De Rosa, J.; Pontolillo, D.M.; Grimaldi, G.M. Monitoring and analysis of an earthflow in tectonized clay shales and study of a remedial intervention by $\mathrm{KCl}$ wells. Riv. Ital. Di Geotec. 2017, 51, 48-63.

40. Scaringi, G.; Pontolillo, D.M.; De Rosa, J.; Di Maio, C.; Caputo, V. Variations of Na+ and K+ concentrations in the pore fluid of a clayey soil affected by landslides: Effects on shear strength and creep behaviour. In Proceedings of the XVII European Conference on Soil Mechanics and Geotechnical Engineering ECSMGE, Reykjavik, Iceland, 1-6 September 2019; Sigursteinsson, H., Erlingsson, S., Bessason, B., Eds.; ISSMGE Online Library, 2019; pp. 1038-1044.

41. De Rosa, J.; Pontolillo, D.M.; Di Maio, C.; Vassallo, R. Chemical clay soil improvement: From laboratory to field test. Procedia Eng. 2016, 158, 284-289. [CrossRef]

42. Pontolillo, D.M.; De Rosa, J.; Scaringi, G.; Di Maio, C. Clay creep and displacements: Influence of pore fluid composition. Procedia Eng. 2016, 158, 69-74. [CrossRef]

(C) 2020 by the authors. Licensee MDPI, Basel, Switzerland. This article is an open access article distributed under the terms and conditions of the Creative Commons Attribution (CC BY) license (http://creativecommons.org/licenses/by/4.0/). 